\title{
SULT, APPETIT OG MÆETHED Mellem biologi og kultur
}

I og uden for Danmark viser statistikker, at antallet af personer, der defineres som henholdsvis overvægtige og fede er stigende (Dike 1996; WHO 1997), ligesom forekomsten af spiseforstyrrelser og såkaldt risikoadfærd for spiseforstyrrelser er stigende (Sundhedsstyrelsen 1997). Udviklingen er herhjemme og i de lande, vi normalt sammenligner os med, blevet set som udtryk for en polarisering af vores spisevaner, hvor ikke kun mangel på kontrol eller overdreven kontrol over spisning menes at være stadig mere udbredt (Holm \& Iversen 1997), men også cykliske spisemønstre, hvor den enkelte veksler mellem overspisning og forskellige former for slankeadfærd (Lupton 1996). Mens der er blevet peget på en række tendenser og ændringer både i samfundsindretningen og kulturen (se f.eks. Fishler 1980; Fagt \& Groth 1992; Holm \& Iversen 1997), som de nævnte ændringer i madkonsumtionen kan formodes at hænge sammen med, er det ikke direkte undersøgt, hvordan dette kommer til udtryk i spisningen som konkret aktivitet og erfaring. Appetitten kan her ses som et centralt forskningsområde - dels som det sted, hvor madkonsumtionen kropsligt reguleres, dels som det sted, hvor biologi og kulturelle forestillinger mødes i det enkelte menneske.

Hidtil er det hovedsagelig inden for den naturvidenskabeligt funderede ernæringsforskning, at sult, appetit og mæthed mere systematisk er blevet undersøgt. I dag forskes der især i genetiske faktorers indflydelse på appetitreguleringen i forbindelse med udviklingen af fedme, men også kosten er sammen med betydningen af fysisk aktivitet i stigende grad blevet en vigtig del af den ernæringsfysiologiske fedmeforskning - bl.a. fordi den relativt konstante arvemasse ikke er i stand til at forklare stigningen i fedmeforekomsten. Den kostorienterede fedmeforskning har bl.a. beskæftiget sig med, hvordan egenskaber som madens lugt, smag, temperatur og tekstur samt variation og makronæringsstofsammensætning alle er faktorer, der har indflydelse på appetitreguleringen. Ernæringsvidenskaben kan hermed siges at være kommet tættere på selve måltidet og erfaringsbaserede dimensioner af madkonsumtionen. Det er dog stadig hovedsagelig appetitten set som resultat af fysisk og biokemisk respons på forskellige kostsammensætninger, der eksperimentielt undersøges, når man skal forklare, hvordan energiindtaget kontrolleres.

En samfundsvidenskabelig forståelse af, hvordan sult, appetit og mæthed konstitueres som subjektiv erfaring, må formodes at kunne komplementere de ernæringsfysioforskningsresultater. Selvom den samfundsfaglige interesse for appetitten har været no- 
get sporadisk, er der, særlig inden for de senere år, udført både sociologiske og kulturanalytiske studier, som på forskellig vis berører aspekter af den subjektivt erfarede appetit. At der her ikke fokuseres lige så specifikt på appetitten som inden for den ernæringsfysiologiske forskning, synes i sig selv at være en pointe, idet appetitten gerne belyses som en del af en større social og kulturel sammenhæng. Appetitten kan derfor også ses som et forskningsområde, hvor centrale tendenser i madkulturen kan aflæses.

Efter at have præsenteret forskellige studier af og tilgange til appetitten vil jeg her forsøge at skitsere en analytisk ramme, som er i stand til at rumme både ernæringsfysiologiske og samfundsvidenskabelige forskningstilgange til appetitten. Det vil i forlængelse heraf være en pointe, at den subjektivt erfarede appetit med fordel kan studeres som funderet i såvel de fysiologiske processer og mekanismer, der ligger til grund for appetireguleringen, som de sammenhænge og betydninger, mad og spisning indgår i og tillægges. Med til artiklens historie hører, at den bygger på nogle af de overvejelser, der er gået forud for den samfundsvidenskabelige del af et tværfagligt forskningsprojekt om sult, appetit og mæthed på Forskningsinstitut for Human Ernæring.

\section{Fire analytiske niveauer}

Foruden at være blevet analyseret som interaktionen mellem næringsstoffer og fysiologi er mad og spisning blevet analyseret som centralt for vores selvoplevelse og måder, hvorpå vi lever i og gennem vores krop (Lupton 1996; Taylor 1989), som et symbolsk medium, hvormed grænser sættes mellem sociale klasser, religioner, køn og faser i livscyklus (Bourdieu 1984; Douglas 1975) og som et middel til at etablere og symbolisere kontrol over kroppen gennem diæter og kostanbefalinger (Turner 1992). Jeg vil fastholde disse forskellige tilgange i den følgende fremstilling af studier af sult, appetit og mæthed ved at skelne mellem den fysiologiske, individuelle, sociale og politiske appetit som fire empirisk overlappende, men analytisk differentierbare niveauer. Inddelingen er inspireret af antropologerne Nancy Scheper-Hughes og Margaret Locks skelnen mellem forskellige samfundsvidenskabelige studier i henholdsvis den individuelle, den sociale og den politiske krop (Scheper-Hughes \& Lock 1987:7-8):

Med den individuelle krop refererer de til studier af den grundlæggende og umiddelbare erfaring af at være et krops-selv. Selvom de fleste mennesker har en intuitiv fornemmelse af at være kropslige personer, der eksisterer adskilt fra andre individuelle kroppe, viser studierne, at der er stor kulturel variation i, hvordan kroppens konstituerende dele og hermed menes ,kødet“" såvel som bevidstheden, psyken, sjælen og selvet - tænkes at være relateret til hinanden, og hvordan kroppen opleves som sund og syg.

Med den sociale krop refererer de til studier af, hvordan kroppen bruges som et ,naturligt" symbol på forskellige samfundsmodeller. Den sunde krop er f.eks. blevet analyseret som symbol på samfundet som en organisk helhed, den syge krop for social disharmoni, konflikt og disintegration. Modsat bruges også samfundet som en model til at forstå kroppen med. Jeg vil her føje et interaktionistisk niveau til den sociale krop, fordi produktionen og bekræftelsen af social og kulturel betydning oftest både opstår gennem og analyseres som en del af social interaktion.

Som et tredje analyseniveau omtales den politiske krop, som refererer til analysen af forskellige kropspolitikkers regulering, overvågning og kontrol af kroppe (individuelle 
som kollektive) i reproduktion, seksualitet, arbejde og fritid, i sygdom og i andre former for afvigelser og forskelle mennesker imellem. I disse politikker afhænger stabiliteten $\mathrm{i}$ kropspolitikken af dens evne til både at regulere befolkninger og at disciplinere den individuelle krop.

Jeg vil her supplere de tre ovenstående analyseniveauer med den fysiologiske krop og hermed henvise til kroppen, som den er blevet analyseret inden for et naturvidenskabeligt forståelsesunivers, dvs. som fysisk og biokemisk organisme, hvis anatomiske og funktionelle egenskaber kan beskrives i overensstemmelse med generelle videnskabelige love.

Selvom studier af den fysiologiske, individuelle, sociale og politiske krop betjener sig af forskellige teoretiske tilgange og epistemologier, er nødvendigheden af at gå på tværs af sådanne traditionelt distinkte forskningstilgange blevet anført. Det er f.eks. en pointe hos Nancy Scheper-Hughes og Margaret Lock, at følelser må studeres som en samtidighed af det individuelle, sociale og politiske niveau, fordi de på en gang erfares individuelt og kollektivt, udtrykkes socialt gennem forskellige symbolske repræsentationer samt er underlagt regulering, disciplinering og kontrol gennem politiske, sociale og $\emptyset$ konomiske processer. Følelser kan i den forstand ses som en matrice for de tre kroppe.

I et senere studie udført i Brasilien analyserer Nancy Scheper-Hughes også sult som en blanding af biologiske, psykologiske og symbolske betydninger (Scheper-Hughes 1992:136). Antropologen Deborah Lupton har påpeget, at kropslige erfaringer og fysiske fornemmelser som sult, mæthed og smagspræferencer i vores egen, fødevaremæssigt mere priviligerede del af verden må analyseres som konstrueret af og medieret gennem samfundet og kulturen. Dermed udelukker Lupton ikke en vis grad af ren fysiologi, men sult, mæthed og smagspræferencer må tillige forstås som subjektive erfaringer, der er under stærk påvirkning af sociale og kulturelle forhold (Lupton 1996:13). Mere specifikt vil jeg foreslå, at de fire tilgange til appetitten kan fremstilles som indlejrede i hinanden (se fig. 1). Figuren viser, hvordan appetittens forskellige niveauer kan ses som henholdsvis kontekstualiserede af og kontekstualiserende hinanden i forskellige forhold.

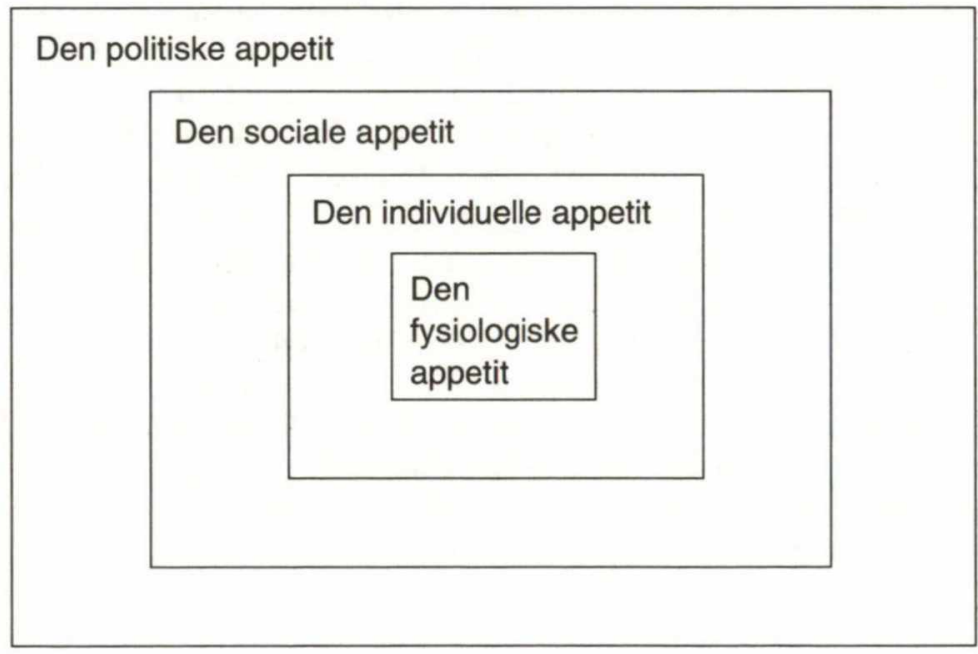

Figur 1: Appetittens niveauer 
Den følgende fremstilling af studier i appetitten og appetitrelaterede problemstillinger efter de fire forskellige analytiske kropsblikke vil ikke være udtømmende (og det gælder i særdeleshed studier, der beskæftiger sig med den fysiologiske appetit). Den vil heller ikke være gennemført stringent i forhold til inddelingen, hvilket imidlertid hænger fint sammen med artiklens påpegning af sammenhænge de forskellige niveauer imellem. Når der alligevel er grund til at fastholde inddelingen, er det dels fordi den som sagt i en vis udstrækning repræsenterer forskellige forskningstilgange og epistemologier, dels af hensyn til overskueligheden i fremstillingen.

\section{Den fysiologiske appetit}

Sult, appetit og mæthed er centrale begreber inden for ernæringsvidenskaben og ses herudover også som sammenhængende fænomener. Appetitreguleringen menes sikret gennem balancen mellem sult og mæthed, der ses som bestemt af en række blodbårne og nervøse signaler, det være sig lokale faktorer i mave-tarmkanalen, tyggeprocessen, stofskifteprocessen, hormonelle påvirkninger og ydre stimuli (Astrup \& Rössner 1997:2801). Fysiologisk defineres sult som krampeagtige, ubehagelige fornemmelser i mavetarmkanalens øverste del, ledsaget af sammentrækninger af mavesækken. Den kan desuden forstærkes af lavt blodsukker, og medføre irritation og koncentrationsbesvær (LST 1987:13). I modsætning hertil defineres appetitten som ønsket om eller lysten til bestemte slags mad, ofte udløst af smags-, lugt-, syns- eller høreindtryk, ligesom også erindringer, forventninger og følelser anses for at spille en rolle (op.cit.). Mens sult defineres som uselektiv, fordi den i princippet menes at kunne tilfredsstilles med alle energigivende fødevarer, defineres appetit som selektiv (Astrup \& Rössner 1997).

Mæthed menes påvirket af en række mæthedsmedierende processer både inden for måltidet og mellem måltider. Der skelnes i den forbindelse mellem indtraedende mathed som den mæthed, der afslutter et måltid, og mathed som den mæthed, der følger efter et måltid, og som derved er med til at bestemme tidsrummet mellem måltiderne (se f.eks. Blundell 1996). De mekanismer, som er involveret i afslutningen af et måltid, og som siden opretholder følelsen af mæthed, beskrives som forårsaget af forskellige effekter, der strækker sig fra, at vi ser, lugter og tænker på maden til effekten af dens nedbrudte og absorberede bestanddele. Mere specifikt skelnes der mellem fire mæthedsmedierende effekter, der groft klassificeres som henholdsvis sensoriske, kognitive, postingestive og postabsorbtive, og som til dels refererer til kronologisk forløbende faser i vores måltidscyklus (op.cit.). Med sensoriske effekter menes madens lugt, smag, temperatur, konsistens og tekstur, mens kognitive effekter henviser til de overbevisninger og den viden, vi har om den mad, vi spiser, og de forskellige effekter, vi mener, den har på os. Postingestive effekter refererer til mekanismer som mavesækkens fyldningsgrad, tømningshastighed, dannelsen af hormoner og stimuleringen af kemiske receptorer i mave-tarmsystemet. De postabsorptive effekter henviser til måltidets nedbrudte bestandele (metabolitterne glukose, aminosyrer og fedtsyrer), efter de er blevet absorberet og optaget i blodet.

Mens madens sensoriske egenskaber primært menes at påvirke mætheden umiddelbart før og inden for måltidet (satiation), kan kognitive, postingestive og postabsorptive effekter påvirke den oplevede mæthed både inden for og mellem måltiderne. Postabsorptive effekter træder dog oftest først i kraft ved måltidets afslutning, og madens sensoriske 
kvaliteter betyder i visse tilfælde, at postingestive signaler overhøres. I praksis interagerer de forskellige mekanismer og giver en samlet effekt på mætheden. Indlæring og hukommelse har f.eks. betydning i de tilfælde, hvor bestemte fødevarers sensoriske egenskaber associeres med bestemte postabsorptive effekter, idet allerede lugten og smagen af maden forbereder de postabsorptive processer, som følger.

De senere års forskning viser i forlængelse heraf, at forskellige kostsammensætninger, men med samme kalorieindhold, har forskellig mættende effekt, fordi forskellige makronæringsstoffer indgår i separat regulerede stofskifteprocesser, men også pga. de nævnte sensoriske, kognitive og fordøjelsesregulerede processer. Mens protein og kulhydratrig føde har en kraftig indflydelse på mæthedsfølelsen inden for måltidet, har en fedtrig kost vist sig mere kontroversiel. Det skyldes ikke kun, at sammenhængen mellem indtaget og forbrændingen er dårligere koblet for fedt end for protein og kulhydrat, men også at fedts smagsbærende egenskab og meget høje energitæthed gør det muligt at konsumere store mængder energi så hurtigt, at hæmmende signaler til appetitten inden for måltidet bliver for svage eller langsomme til, at de kan forhindre et stort indtag (Blundell \& King 1996:149). Studier viser desuden, at man ud fra en kaloriebetragtning spiser mindre af ensidige, homogene måltider end af måltider bestående af flere forskellige komponenter og sensoriske kvaliteter, også kaldet ,sensorisk bestemt mæthed“ (ibid). Balancen mellem smagseffekter og hændelser i forbindelse med henholdsvis fordøjelsen og forbrændingen menes at have en samlet indflydelse på, hvordan forskellige kosttyper påvirker appetitten. I forklaringen af, hvor meget vi spiser, sættes madens svækkelse af sulthæmmende faktorer af samme grund over for madens velsmag, dvs. den subjektivt oplevede nydelse ved at spise maden. Tendensen til, at meget energitæt mad fører til, at vi spiser mere målt i kalorier, kan som sådan forstærkes gennem madens sanselige kvalitet.

Med den stigende fokusering på sult, appetit, fyldthed og mæthed har ernæringsvidenskaben udvidet sit fokus fra kalorier i maden og fordøjelses- og forbrændingsprocesser i kroppen til også at omfatte mere subjektive kropslige erfaringer, som er under indflydelse af kognitive effekter og smag. Sult, appetit og mæthed analyseres dog gerne som et forklaringsprincip, man kan slutte sig til gennem observation og måling af en række direkte fysiologiske hændelser, mere end som de specifikke følelser, der er knyttet til begæret efter at spise mad. I det omfang erfaringer af sult, appetit og mæthed undersøges specifikt, gøres det med VAS-scores (visual analogous scores), hvormed subjektive angivelser af henholdsvis sult, appetit, fyldthed og mæthed bestemmes numerisk. Som nævnt indledningsvis er det derfor ikke så meget selve den subjektive erfaring af sult, appetit, fyldthed og mæthed, der søges forstået som de forskellige fysiske og biokemiske processer og stimuli, der menes at ligge til grund herfor.

\section{Den individuelle appetit}

Til studierne af den individuelle appetit hører bl.a. fænomenologisk inspirerede analyser af den subjektivt erfarede og erfarende krop. Dette medfører et andet og mere kvalitativt perspektiv, men også et delvis andet genstandsfelt end det ernæringsvidenskabelige, fordi store dele af de processer, som gøres til genstand for de fysiologiske appetitstudier, ikke er tilgængelige for individuel erfaring. Dermed ikke sagt at den fysiologiske appetit er irrelevant set i den individuelle appetits perspektiv. Drew Leder har vist, hvordan na- 
turvidenskabens specialiserede blik kan bruges, når den subjektivt erfarede krop skal beskrives. Gennem blotlæggelse af kropsområder, der ellers ligger utilgængelige for det almindelige blik, kan sådanne observationer og erkendelser afdække aspekter af vores kropslighed, der er utilgængelige for det almindelige blik, og klargøre „strukturelle korrelater til vores intentionelle kapaciteter" (Leder 1990:7). Mere konkret trækker Leder på sådanne naturvidenskabelige erkendelser i beskrivelsen af fordøjelsens fanomenologi, som det måske ville være mere rigtigt at kalde for appetitreguleringens fanomenologi, idet Leder beskæftiger sig med såvel fordøjelse som spisning og forbrændingen af mad. Subjektive erfaringer af sult, appetit, fyldthed og mæthed synes på den baggrund at kunne kontekstualiseres som punktoplevelser i den ovenfor beskrevne række af fysiske og biokemiske processer, der generelt kendetegnes ved et subjektivt kropsligt fravær.

Særlig skelner Leder mellem, hvad han kalder den ydre og den indre krop. Den ydre krop refererer til kroppens overflade eller yderside, og dermed vores sanseapparat, bevægelsesevne og udtryksevne. Den ydre krop er som sådan den del af os, der ligger åben for og muliggør interaktion med omverdenen. Den indre krop henviser derimod til vores kropslige dybde, som foruden fordøjelsen omfatter respirationen, hjertekarsystemet, de indre kønsorganer, det endokrine system og milten som fysiske lokaliteter. Ifølge Leder adskiller den ydre og indre krop sig ikke bare i deres virke gennem forskellige fysiologiske mekanismer, men også ved at være kendetegnet ved forskellige fænomenologiske erkendelsesformer. Sammenlignet med ydreperceptionen, dvs. kroppens perception af omgivelserne gennem de fem sanser, er indreperceptionen, dvs. sansningen af de indre organer og tilstande, således kendetegnet ved kvalitativ reduktion, rumlig tvetydighed og en rumlig og tidslig diskontinuitet (Leder 1990:39).

Med kvalitativ reduktion mener Leder, at indreperceptionen bærer præg af en grovhed og generalitet $\mathrm{i}$ aflæsningen af signaler sammenlignet med ydreperceptionens mange nuanceforskelle, når vi føler, hører, smager og lugter. Følelser af fyldthed, krampe eller følelsen af mavesyre er f.eks. ifølge Leder stort set udtømmende for de vanlige sensoriske erfaringer, der er mulige i denne region - en antagelse, jeg senere skal stille spørgsmålstegn ved. Den begrænsede indreperceptive differentieringsevne er tillige centreret omkring affektivt ladede fornemmelser. Den mere nøgterne skandering af verden, som ydreperceptionen muliggør gennem adskillelsen mellem iagttager og iagttaget, er ikke på samme måde mulig ved indreperceptionen, der, fordi den ,tager os indefra“, ofte opleves som en emotionel insisteren, som det er tilfældet med det ubehag, der knytter sig til at have mavepine. Den er tillige mest artikuleret i forbindelse med dysfunktion, hvilket har en klar biologisk funktion, fordi det fremtvinger restituerende handlinger, som det f.eks. er tilfældet med den sult, der får os til at spise.

Med rumlig tvetydighed menes en manglende evne til præcist at kunne lokalisere det erfarede. F.eks. er mange af de indre organer ikke i sig selv i stand til at registrere smerte, der ofte udtrykker sig i andre regioner af kroppen end der, hvor den kommer fra. Også sult og tørst erfares ofte som en blanding af noget lokalt og noget, der involverer hele kroppen. Sult opleves således ikke kun som et hul i maven, men som en tyngde i hele kroppen og en længsel i munden. Den er som sådan en kompleks blanding af tyngde, udmattelse, målrettet trang og ubehagelige fornemmelser, der, selvom de har deres knudepunkter, tvetydigt inddrager hele kroppen.

Endelig er indreperceptionen karakteriseret ved både rumlig og tidslig diskontinuitet. Det er karakteristisk, at fordøjelsesprocessen optræder som periodiske punktoplevelser 
omkranset af fravær. Mens halsbrand, overfyldthed, mavekrampe og afføringsbehov er tilgængelig for erfaring, er den enzymatiske udskillelse af maden, de bølgende tarmbevægelser samt spredningen og den aktive transport af næringsstoffer nedsænket i en tilsyneladende uigennemtrængelig stilhed. Årsagsforhold opleves derfor også ofte som uigennemskuelige. Man kan f.eks. have svært ved at vide, om ondt i maven skyldes sult, stress eller at man har spist noget, man ikke kunne tåle.

Selvom det typisk er sådanne øjeblikke af ubehag, vi registrerer, mens de ordinære funktioner stort set er umærkelige, understreger Leder, at dette er relativt. Ved at fokusere bevidst på maveregionen, muliggøres eksempelvis en rudimentær oplevelse af sensorisk neutralitet som hverken fyldt eller tom, lystfyldt eller smertende. Denne ,lette aura“ er ikke betydningsløs. Den er tonet med positivitet, fordi den fortæller, at sulten er stillet, og at man ikke er syg. Dette synes at være tilfældet med mæthed, som Leder dog ikke eksplicit beskæftiger sig med. Det kropslige velbehag, der kan være forbundet med mæthedsoplevelsen efter et godt måltid, og som evt. kan forlænges med en cognac og en god cigar, afløses således som regel hurtigt af en optagethed af ikke-kropslige forhold.

Foruden den ringere erfaringstilgængelighed adskiller den indre krop sig desuden fra den ydre krop ved at være relativt uafhængig af bevidst kontrol og styring. F.eks. kan sult ses som udtryk for et fysiologisk krav, der regerer os, selvom den personlige subjektivitet kan vælge, hvordan vi opfylder dette biologiske behov, ved midlertidigt at udsætte et måltid eller at spise bestemte slags mad frem for andre slags. Men vi besidder af indlysende grunde ikke endelig autonomi. Hvis man sulter eller sulter sig selv i længere tid, vil det på et tidspunkt være livstruende. Modsat under spisningen, som man er personligt ansvarlig for, og som man kan stoppe, hvis begæret skifter retning, eller nogen beder en om det, indlemmes maden $\mathrm{i}$ det hele taget $\mathrm{i}$ et andet viljesrum, når den synkes; strubelågene foldes, sammentrækninger i spiserøret fører maden videre nedefter, mavemunden åbner sig, tarmene tager over med deres indviklede rytmer, som sammenblander, udskiller og komprimerer maden. Denne forskel til trods hersker der en stor afhængighed mellem den ydre og den indre krops respektive funktionsmåder. Mens den indre krops bevægelsesmuligheder både er begrænsede og automatiske, er de objekter, den arbejder med allerede udvalgte, filtrerede og kanaliserede af kroppens overflade. At de fikserede bevægelsesmønstre er tilstrækkelige, må derfor ses på baggrund af overfladens plasticitet, ligesom overfladen omvendt frigøres gennem dybdens automatik (Leder 1990:51).

De her beskrevne forskelle mellem den ydre og indre perception viser, at der er kvalitative perceptionsforskelle i appetitreguleringens forskellige komponenter. Mens sultens forankring i den indre krop perceptionsmæssigt er knyttet til sansningen af vores egen fysiologi som dys-appearance, er appetitten, som medieret gennem den ydre krop, relationelt bestemt ved i højere grad at være rettet mod sansningen af bestemte slags mad, og ikke vores egen krop. Vi smager netop på maden og ikke på vore smagsløg, ligesom vi kan bide i alt andet end vore egne tænder for at tage nogle af Leders eksempler. Appetittens beroende på ydreperceptionens sansemodaliteter gør os desuden i stand til at skelne mellem et svimlende antal nuanceforskelle i madens udseende, duft og smag, mens differentieringsmulighederne synes stærkt reduceret, når det gælder sult og mæthed.

Distinktionen mellem oplevelsen af den indre og ydre krop synes dog i flere tilfælde at kunne relativeres. Rent funktionelt viser den indre og ydre krop sig at hænge snævert sammen, f.eks. opleves vore sanser gerne at blive svækkede af sult og skærpede af den energi, som mad giver os. Også det oplevede forhold mellem sult og appetit, og dermed 
mellem den indre og ydre krop, synes at være komplekst. Som subjektiv oplevelse beskrives sult og appetit af Deborah Lupton dels som samtidige fænomener, f.eks. kan appetit opleves som sult ,krydret med følelse“, når vores favoritmad tilberedes, og munden løber i vand. Men appetitten efter bestemte slags mad kan også erfares uafhængigt af sultfølelsen, ligesom sult kan forekomme, uden at vi har den store appetit. Manglen på appetit er f.eks. ofte forbundet med følelser som uro, nervøsitet, angst, sorg eller endda glæde, opstemthed og forelskelse. Selvom vi i sådanne følelsesfulde tilstande kan miste appetitten, så bare tanken om mad er kvalmende, kan sulten stadig opleves som gnavende i den tomme mave. Modsat kan sulten, hvis den ikke stilles og er tilstrækkelig stærk, fremkalde følelser som uro, irritation og vrede (Lupton 1996:33).

Flere studier synes i det hele taget at kunne fortolkes i retning af, at indreperceptionen i stigende grad er blevet til et reflekteret semantisk felt. Det kunne her være en pointe, at netop den kvalitative reduktion, tvetydighed og diskontinuitet, der ifølge Drew Leder kendetegner den indre krops perceptionsformer, gør den til et velegnet subjektivt fortolkningsfelt i en tiltagende krops- og madreflekteret kultur. Selvom Leder ikke kommer ind på denne mulighed, er det interessant, at han, trods den indre krops altovervejende autonomi, peger på muligheden af indirekte at udøve kontrol over den indre krop, fordi de vegetative processer $i$ et vist omfang afhænger af udvekslinger med omgivelserne. Man kan f.eks. slutte sig til en hel del om fordøjelsen ved at sammenholde det, man spiser, med sin afføring. Man kan, som det fremgik af de fysiologiske appetitstudier, udøve kontrol over dette $\mathrm{i}$ valget af spise og drikke, ligesom man indirekte kan assistere sine organer ved at undgå bestemte slags mad, f.eks. i forbindelse med sygdom (Leder 1990:49). Man kan desuden udøve kontrol over, hvilken mæthedsfølelse man får, alt efter hvad man spiser, og hvor hurtigt man spiser det.

Oplevelsen af kontrol eller svigtende kontrol over appetitten synes i den forbindelse for mange mennesker desuden at være tæt knyttet sammen med deres selvfølelse og selvforståelse. Alment eksistentielt er spisning af mad ifølge madsociologen Claude Fischler både af vitale og symbolske grunde kilde til bekymring, fordi det vi spiser, bliver en del af os. Vi indoptager i bogstavelig forstand maden, når den krydser grænsen mellem det, der er uden for kroppen, og kroppen selv (Fischler 1988a:282). Deborah Luptons føromtalte undersøgelse synes at pege i retning af, at denne universelle tendens til ængstelse forstærkes i den vestlige verden, idet den viser, at følelsen af fremmedgørelse og adskillelse fra kroppen ikke er forbeholdt mennesker med spiseforstyrrelser. Mange andre har lignende oplevelser om end i mindre udbredt grad. Når de ikke er i stand til at kontrollere begæret efter deres yndlingsmad og tilpasse sig slankekost, oplever de skyld, skam, frustration og væmmelse ved sig selv (Lupton 1996:141). Sådanne følelser viser sig ikke kun at være knyttet til den substantielle krop, men også til kroppens udseende. Navnlig fed mad opleves som det, der gør kroppen ulækker, som for mange er det samme som at være fed (Lading 1987:24).

\section{Den sociale appetit}

I forlængelse af sin analyse af fordøjelsens fænomenologi påpeger Leder, inspireret af fænomenologen Merleau-Ponty, at også intersubjektivitet er af afgørende betydning for vores selvoplevelse. Kroppen bevidstgøres gennem erfaringen af vores medmenneskers 
kropslighed og gennem deres blikke rettet tilbage på vores krop. For at blive os selv må vi derfor først blive objekt for andre ved at inkorporere deres blik (Leder 1990:1992). Hos Merleau-Ponty beskrives kroppens væren-i-verden derfor som præget af en grundlæggende tvetydighed; på den ene side er den genstand for de andres blik, og på den anden side er den bærer af den subjektivt oplevede sanselighed og selvbestemmelse. At selvet på den måde bliver til gennem social interaktion, medfører desuden, at det kan variere fra en sammenhæng til en anden.

Leder bruger ikke for alvor denne indsigt i kroppens intersubjektive karakter i sin analyse af appetitten, men det synes oplagt, at forståelsen af appetitten kan beriges gennem en sådan socialfænomenologisk optik. At de andres blik af naturlige årsager hovedsageligt er rettet mod kroppens ydre fremtoning, dens proportionering og adfærd, kædes, som vi allerede har set det i Luptons studie, gerne sammen med evnen til at kontrollere kroppens behov og begær. Helt elementært gælder det desuden, at sult, appetit og mæthed opleves forskelligt i forskellige situationer, alt efter om vi er alene eller sammen med andre, om vi kan lide disse andre, føler os trygge ved dem etc. Den samme mad smager ikke bare forskelligt alt efter, hvordan den tilberedes, den får også sin specielle smag afhængigt af, hvem der laver den, hvem vi spiser sammen med, og hvor vi spiser. Appetitten og smagen er som sådan både situationelt og intersubjektivt bestemt (Andersson 1980:29). Væsentlig for forståelsen af appetitten bliver i den forbindelse tillige analyser af, hvordan måder, vi spiser på, og kroppens form samt sammenhænge herimellem omgærdes af en række sociale konventioner og kulturelle forestillinger.

Sociologen Georg Simmel har i en klassisk artikel om måltidets sociologi beskrevet, hvordan det ,,civiliserede måltid“ er karakteriseret ved forbud og regler, hvis formål det er at hæve måltidets ,fysiologiske primitivitet“ og ,uundgåelige almenhed“ op i en samfundsmæssig betydningssfære. Gennem faste måltidsmønstre og æstetisering af måltidet overvindes spisningens naturalisme ved at etablere en række forskrifter for, hvornår, hvordan og hvad der spises (Simmel 1993:3). Til forestillingen om at være civiliseret og dannet hører derfor evnen til at kunne kontrollere appetitten både mellem måltider og inden for det enkelte måltid. Også den franske sociolog Pierre Bourdieu har analyseret æstetiseringen af måltidet, men særlig som noget, der gør sig gældende i borgerskabets omgang med mad, hvor behovsudsættelse, luksus og avanceret smag har været en måde at lægge afstand til arbejderklassens forkærlighed for det funktionelle, hedonistiske og traditionelle måltid. Den borgerlige måltidshabitus bygger således på orden, begrænsning og sømmelighed, mens arbejderklassen ifølge Bourdieu har et langt mere naturligt og umiddelbart kropsligt forhold til at spise - og spise sig mæt (Bourdieu 1984:193-4).

Foruden, og vel også i modsætning til, dette naturargument taler Bourdieu om forskellige „kropsskemaer“ eller kropslige habitus, der styrer den fysiske tilgang til spisehandlingen. En maskulin spisemåde er f.eks. i nogle miljøer forbundet med den ideale mandekrop, som den kraftfulde, store og stærke krop med bydende og brutale behov, modsat kvinder, der forventes at tilsidesætte egne behov. Arbejdsmænd forventes derfor ikke at spise fisk og søde sager, der skal pilles og suttes, og som sådan anses for at være mad for børn og kvinder. Rent biologiske forskelle synes i den forstand at blive understreget og accentueret symbolsk gennem forskelle i holdninger i gestik, positur og adfærd, som udtrykker placeringen $\mathrm{i}$ og forholdet til den sociale verden (ibid.). ${ }^{13}$

Teorier om mad og modernitet peger på, at mad og måltider i det hele taget skulle have tabt i substantiel værdi, samtidig med at dens symbolske betydning er $\emptyset$ get. Ifølge 
Roland Barthes er mad og måltidernes associative betydning ekspanderet som et led i moderniteten, hvilket viser sig ved, at deres tegnværdi er blevet vigtigere end deres næringsværdi. Hvor mad førhen primært blev brugt til at markere festlige anledninger, er den nu tillige udtryk for aktivitet, arbejde, sport, præstation og fritid. At spise er på den måde i stigende grad blevet en handling, der overskrider sine primære mål ved at erstatte, opsummere eller signalere anden adfærd (Barthes 1979:172). Også Claude Fischler har påpeget, at udvælgelsen af mad ikke udelukkende kan forstås ud fra ernæringsvidenskabelige parametre som fysiske behov, perceptuelle og kognitive mekanismer, samt madens næringsværdi og sensoriske egenskaber, men også må ses på baggrund af kulturspecifikke madpræferencer, klasseforskelle, køn og alder (Fischler 1988a). Fischler mener i det hele taget, at denne skelnen mellem det biologiske og kulturelle er mere teoretisk end reel, idet madens sociale og kulturelle betydninger og normer internaliseres og indskrives i vores smagspræferencer og stofskifteprocesser (Fischler 1980:983; 1988b) og dermed også i appetitreguleringen. Den svenske sociolog Sten Anderssons beskrivelse af, hvordan mæthedsoplevelser er knyttet til forskellige køns- og klassespecifikke madpræferencer, er i den sammenhæng interessant. Mens en let mæthed ifølge Andersson associeres med en moderne effektiv livsstil, med noget kvindeligt og med noget frigørende, associeres en tung mæthed med en mere traditionel livsstil, med hårdt fysisk arbejde og med det mandlige (Andersson 1980).

Foruden at være knyttet til madens symbolværdi er appetitten blevet knyttet til kroppens symbolværdi. Deborah Lupton beskriver f.eks., hvordan den fede mandekrop kulturhistorisk er blevet associeret med grådighed, pondus og magt; den indgyder som sådan frygt, mens den fede kvindekrop er blevet associeret med det bløde passive og hjælpeløse, og som sådan mest af alt kalder på omsorg (Lupton 1996:139). I det omfang den fede kvindekrop stadig sammenkædes med sådanne symbolske konnotationer, kan det formodes, at stadig flere kvinder direkte føler sig berørt af dem, idet kvinder er blevet federe, mens det kvindelige kropsideal er blevet slankere. Således vejer Miss America i dag kun $85 \%$ af den idealvægt som bruges til screening for anorexia nervosa (Lauren Lisner 1997:78). Til gengæld synes den fede mandekrops symbolværdi stærkt ændret. Mere end at være frygtindgydende symboliserer den midaldrende mand med vom i mange miljøer tab af ungdom, status og respekt. Vigtigst er det imidlertid, både når det gælder mænd og kvinder, at den fede krop ses som den ukontrollerede krop - ikke at kunne styre appetitten er ensbetydende med ikke at kunne styre sig selv - mens den slanke krop forbindes med kontrol og rationalitet (Lupton 1996:140).

\section{Den politiske appetit}

Inspireret af filosoffen Michel Foucault har sociologen Bryan S. Turner studeret diæternes indtog i midten af det 18. århundrede, hvor de havde strenge moralske konnotationer. Fedme blev associeret med moralsk afvigelse, som i modsætning til i dag særlig ramte rige mennesker med en doven og luksuriøs livsførelse. Årsagen blev tillagt de sjældne delikatesser, den righoldige mad og de fine vine, som mentes at ophidse appetitten, sanserne og lidenskaberne til vellyst. Datidens store diætist George Cheyne frarådede derfor sine klienter den ophidselse af sanserne, som en alt for kunstfærdig tilberedning af maden førte med sig. Ansvarlig for den vellyst, der skulle disciplineres, holdtes altså den 
appetitvækkende og smagsskærpende mad, som importeredes i perioden (Turner 1992:112-3).

Analyser af vor tids ernæringsoplysning og kostanbefalinger viser, at appetitten i vores århundrede ikke kun anses for at være problematisk for de velstillede. I en undersøgelse af ernæringsoplysning foretaget af Statens Husholdningsråd i Danmark fra 193686 fremgår det, at mens appetitten i efterkrigstidens ernæringsoplysning blev betragtet som det, der naturligt markerede grænsen for, hvor meget man havde behov for at spise, indsættes kostberegninger af det daglige madindtag i starten af 1960'erne som det, der sikrer en rigtig regulering af kostindtagelsen. Det angives i skemaer, hvilke mængder (målt i gram) mennesker i forskellige aldre bør spise af forskellige kosttyper. Følger man madplanens kostberegninger, er der derfor ikke det store behov for at lytte til egen sultog mæthedsfølelse (Christensen 1998).

Selvom ernæringsoplysningen i den forstand står i modsætning til tidens store udbud af billige og lækre madvarer, tyder noget på, at den ikke står i modsætning til kulturen som sådan. Paradoksalt nok kan hensigten med forbrugersamfundets moderne kost ses som frembringelsen af lyst - at bevare livet for at $\emptyset$ ge seksualiteten og $\emptyset$ ge nydelsen (Turner 1992:116). Sociologen Mike Featherstone peger på, at kroppen i det hele taget udnævnes til bærer af nydelse i forbrugerkulturen og som sådan både er genstand og subjekt for begær, nydelse og selvartikulering (Featherstone 1982:21-2). Kroppen antager i den forbindelse en ny samfundsmæssig og individuel betydning, idet den bliver stedet for den enkeltes egne sundhedsstrategier, f.eks. jogging, slankekure og fitness, der skal fremme sundheden, som anses for at være grundlaget for et lystfyldt liv.

Det er i den forbindelse blevet fremført, at spisekulturen er præget af ambivalens, idet ængstelse og usikkerhed menes at være en konsekvens af, at vi får nye og ofte modstridende informationer om forholdet mellem mad, krop og sundhed (Lupton 1996:16). Spisekulturen synes i den sammenhæng at kunne analyseres som et samtidigt, men svært foreneligt $\emptyset$ nske om på den ene side at være rationel, selvkontrolleret og selvdisciplineret i omgangen med mad og på den anden side at kunne give efter for impulser, at udtrykke følelser og „,være sand“ over for sig selv, hvilket for mange hænger sammen med at tillade sig mad, som giver nydelse og selvforglemmelse. Kroppen begrebsliggøres på den måde både som kilde til hedonistisk nydelse og eftergivenhed og som moralsk og æstetisk billede (Taylor 1989:116).

Formålet med at gå på diæt har også ifølge Turner skiftet fra hovedsageligt at være den religiøst inspirerede indre renselse gennem faste til særligt at skulle forskønne kroppens ydre. Hvor selvdisciplin førhen blev belønnet med Guds velsignelse, belønnes den nu med skønhed. Denne idealisering af kroppen kan ses som et udtryk for, at forankringen af vores selvforståelse er flyttet fra sjælen til kroppen (Turner 1992:116). Kroppen er i den forbindelse blevet beskrevet som et projekt i stadig tilblivelse, hvor madvalg træffes ud fra idealer om kroppens rette størrelse og form og ud fra forestillinger om fysisk sundhed. Maden er på den måde blevet noget, som bruges til at modulere selvet og kroppen med (Lupton 1996:137). Tendensen ses også i den danske ernæringsoplysning allerede fra 1960'erne, hvor kropsæstetiske argumenter begynder at blive relateret til sundhed. Ernæringsoplysningen begynder i den forstand at forholde sig både til sundhed og æstetik og sammenhængen imellem dem (Christensen 1998).

Sådanne tiltag er blevet analyseret som kønsundertrykkende. Særligt den kvindelige krop er blevet analyseret som en føjeliggjort krop, hvis kræfter og energier menes tilpas- 
set ekstern regulering, underlæggelse, transformation og ,forbedring“ gennem præciserende og normaliserende disciplineringer eksempelvis gennem kost, make-up og påklædning. På den måde menes kvinder at blive gjort mindre socialt orienterede og mere fokuserede på selvmodifikation. Inspireret af Foucault omtaler feministen Susan R. Bordo dette som en særlig form for kønsundertrykkelse, der i høj grad udøves forklædt som selvrealisering (Bordo 1990:23). Som en kritisk kommentar til sådanne fortolkninger er vigtigheden af ikke at forveksle diskursers logik med deres individuelle og samfundsmæssige konsekvenser blevet anført. Diskurser er sjældent ensartede i deres virkninger, og der er under alle omstændigheder et stort antal diskurser med konkurrerende kropsog kostregimenter (Turner 1992:120). Hvad der derfor synes uomgængeligt er, at mad og spisning er blevet en stadig mere reflekteret del af vores liv. Vi både fristes af og konfronteres med mad i stadig flere former og sammenhænge, ikke kun i kraft af den større tilgængelighed, men også gennem ernæringsoplysning og reklamer, hvor madkonsumtionen sammenkædes med sundhed, skønhed og dermed identitet.

\section{Konklusion}

Jeg vil afslutningsvis argumentere for, at den individuelle appetit kan ses som et særligt privilegeret sted at unders $\emptyset$ ge appetitten. Som nævnt bruges subjektive angivelser af sult, appetit, fyldthed og mæthed i den naturvidenskabelige ernæringsforskning til at bestemme forskellige kostsammensætningers indflydelse på appetitreguleringen. Omvendt trækker også den fænomenologisk inspirerede analyse af appetitten på den individuelle krops niveau på ernæringsfysiologiske indsigter. Analyserne af den sociale og politiske appetit viser, hvordan den individuelle appetit er indlejret $\mathrm{i}$ og medieret gennem sociale interaktioner og repræsentationer og fors $\emptyset$ ges reguleret gennem ernæringsoplysningen. Den individuelle appetit kan derfor ses som et knudepunkt mellem biologi og kultur, hvor de forskellige appetitniveauer empirisk mødes. Den udgør derudover det genstandsfelt, som den naturvidenskabelige og den samfundsvidenskabelige ernæringsforskning har tilfælles og dermed kan mødes omkring (se fig. 2).

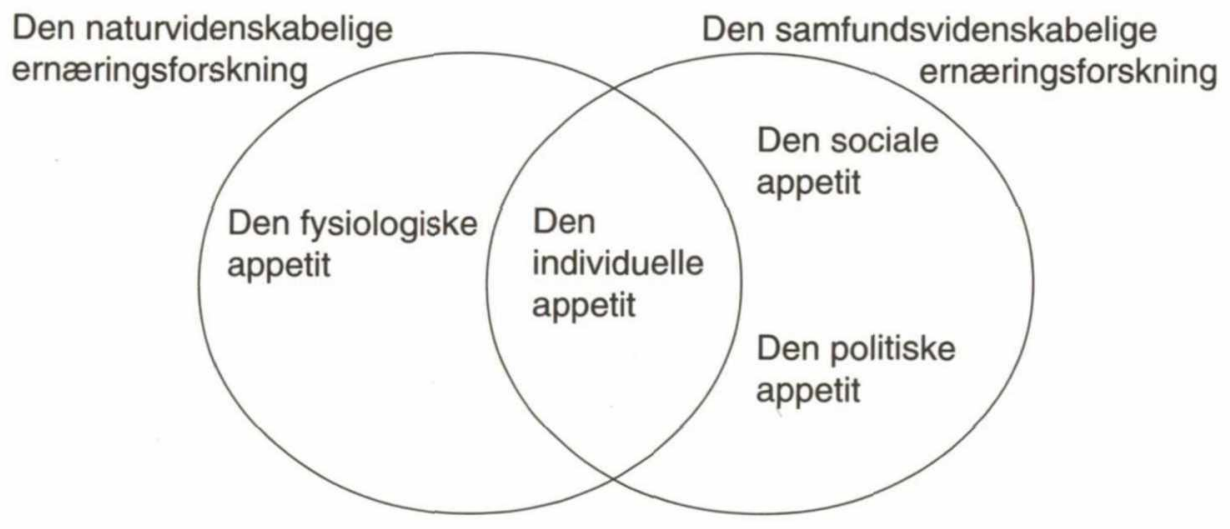

Figur 2: Appetitten som tværvidenskabeligt felt 
Når der er grund til særligt at fremhæve den individuelle appetit, er det endelig, fordi appetitten i stigende grad synes overladt til det enkelte individ. Kravet om at kunne styre appetitten forekommer at være særlig svært i en madkultur, hvor måltidsmønstre og måltidsformater beskrives som værende i opbrud. Det 3-måltidssystem, med to kolde måltider og et varmt, som ellers har været fremherskende i Danmark, menes for mange menneskers vedkommende at være afløst af en tendens til mere løst strukturerede måltidsmønstre (Fagt \& Groth 1992:23-9). Begrebet grazing, at græsse, refererer f.eks. til en forestilling om, at mange moderne mennesker ikke spiser rigtige måltider, men i stedet spiser når som helst og hvor som helst, de får lyst (Holm \& Iversen 1997). I det omfang begrebet er dækkende for vores faktiske omgang med mad, kan der derfor siges at være sket en individualisering af madkonsumtionen. Vi lever i den forstand $\mathrm{i}$ en madkultur, hvor kontrol over appetitten forekommer at være stadig sværere for den enkelte, idet den sociale regulering af måltiderne er blevet stadig mindre, samtidig med at udbudet af billige og lækre fødevarer er blevet større.

Jeg har indledningsvis været inde på, at et stigende antal mennesker lider af spiseforstyrrelser, overspiser eller regelmæssigt går på slankekur. Hvis flere og flere mennesker har et problemfyldt forhold til appetitten, og maden generelt er blevet et område, hvor vores selvforståelse forhandles, må det dog samtidig formodes, at appetitten også i stigende grad fremstår som bevidstgjort erfaring. Appetitten kan som sådan ikke forståes som noget, der bare er, den må studeres som noget, vi har og forholder os til på baggrund af forskellige måltidssituationer, madpræferencer, måltidsmønstre, sundhedsovervejelser, skønhedsidealer og ofte detaljerede forestillinger om kroppens fysiologiske processer og funktioner.

\section{Noter}

1. Undervægt, normalvægt, overvægt og fedme defineres med kropsmasseindekset (Body Mass Index, BMI), der beregnes som vægten divideret med kvadratet på højden (kilo/meter $\left.{ }^{2}\right)$. Undervægt defineres som et BMI på under 18,5, nomalvægt på 18,5-25, overvægt på 25-30, mens fedme ligger over 30 (WHO 1997:10).

2. Ifølge antropologen Nancy Scheper-Hughes har „sultens fænomenologi“ været stærkt underprioriteret, fordi sult er blevet betragtet som noget, der refererer til et basalt instinkt, som samfundsvidenskaben ikke har anset det for relevant at beskæftige sig med.

3. Projektet er finansieret af de statslige forskningsråd. Samarbejdspartnere er professor dr.med. Arne Astrup, mag.scient.soc, ph.d. Lotte Holm og cand.brom., ph.d. Anne Raben.

4. Ordet appetit bruges her som en samlende betegnelse for sult, appetit og mæthed, men bliver i artiklen også brugt i en mere specifik betydning forskellig fra ordene sult og mæthed.

5. Den aktuelle viden om, hvilke hormoner som har fysiologisk betydning hos mennesker, er sparsom, idet den væsentligste del af den ernæringsfysiologiske viden om appetitregulerende mekanismer overvejende bygger på dyreforsøg (Astrup og Rössner 1997:281).

6. Særligt kombinationen af fed og sød mad, som bl.a. er karakteristisk for mange desserter, udgør et stærkt stimulerende kompleks. Et andet eksempel er chips, som er lette, nærmest smelter på tungen og kun kræver lidt tygning på trods af det ofte store fedtindhold.

7. Se endvidere Blundell og Rogers (1991) angående denne skelnen mellem sult, appetit og mæthed som henholdsvis forklaringsprincip og specifik følelse. 
8. Dette er ikke fordi indreperceptionen ikke har både udstrækning og funktion, den har mekaniske receptorer, smertereceptorer og varmereceptorer, men de modulerer alle den samme perception, „den indre følel$\mathrm{se}^{\text {", }}$, snarere end at de åbner op for distinkte erfaringsdomæner.

9. På trods af, at den personlige autonomi ophører med døden, kan sultedøden, som konsekvens af et bevidst valg, som det er tilfældet i forbindelse med sultestrejke, ses som udøvelsen af ultimativ personlig autonomi. Den finder dog som bekendt ikke altid samfundsmæssig anerkendelse, f.eks. når sultestrejkende, på trods af deres politiske motivationer, medikaliseres og tvangsfodres.

10. Bulimikere kan her siges at udgøre en undtagelse, idet grænsen for den indre krops autonomi er flyttet indefter, når maden frivilligt kastes op. Dette lader sig dog som regel kun gøre gennem manipulation af kroppen udefra.

11. Dette, også selvom der i studierne af den sociale appetit, modsat studierne af den fysiologiske og individuelle appetit, kun sjældent fokuseres specifikt på appetitten, der mere end at være interessant i sig selv, behandles som blot et af de mange steder, hvor sådanne sociale regler og kulturelle betydninger kan aflæses.

12. Endnu mere differentieret viste de ,nyrige“ franskmænds madpræferencer sig at gå i retning af tung dyr mad, som vildt og røde bøffer, mens folk i højstatus-professioner vægter det lette, delikate og raffinerede. Højtuddannede med mindre løn vægter det æstetiske hellere end det prangende, f.eks. billig, men original og eksotisk mad. Middelklassen vægter, at man spiser sundt uden at forivre sig, mens arbejderklassen værdsætter et simpelt, men rigeligt måltid (Bourdieu 1984).

13. Dette synes til dels bekræftet i en nyere undersøgelse, som viser, at mænd og kvinder giver forskellige begrundelser for, hvornår de afslutter et måltid. I en spørgeskemaundersøgelse blandt amerikanske studerende oplyser både mænd og kvinder, at de holder op med at spise, når de føler sig mætte, men 55\% angiver også andre årsager. Kvinder angiver her i højere grad hedonistiske årsager, f.eks. at de holder op med at spise, når maden ikke længere smager godt, mens mænd er mere sensitive over for eksterne faktorer, f.eks. at der ikke er mere mad tilbage (Zylan 1996).

14. Ordet diæt har etymologisk set en dobbeltbetydning. Det kan både anvendes i betydningen herredømmet over kroppen og i betydningen herredømmet over borgerne (Turner 1992:109).

15. Det kan derfor formodes, at forskellige personers italesættelse af appetitten bærer præg af variation og kompleksitet, ligesom det enkelte menneske kan forventes at trække på forskellige diskurser i forskellige situationer. Det ligger dog indforstået i diskursanalysen, at de artikulerede diskurser produceres ud fra et sæt af på forhånd givne diskurser, der cirkulerer i kulturen. De valg folk tager, når de præsenterer deres erfaringer og tillægger dem betydning, afslører som sådan et hierarki af diskurser, ligesom de demonstrerer, at der eksisterer konfliktuelle og ofte modsætningsfyldte diskurser.

\section{Litteratur}

Andersson, Steen

1980 Matens Roller - sociologisk gastronomi (Roles of Food: Sociological Gastronomy). Stockholm: Almqvist \& Wicksell Förlag AB.

Astrup, Arne \& Steen Rössner

1997 Kost og Fedme. I: A. Astrup, L. Garby \& S. Stender (red.): Menneskets ernæring fra molekylærbiologi til sociologi. København: Munksgaard.

Barthes, Roland

1979 Toward a Psychosociology of Contemporary Food Consumption. I: R. Forster \& O. Ranum (eds.): Food and Drink in History: Selections from the Annales, Economies, Sociétés, Civilisations. Vol. 5. Baltimore: The John Hopkins University Press.

Blundell, John E. \& Neil A. King

1996 Overconsumption as a Cause of Weight Gain: Behavioural-Physiological Interactions in the Control of Food Intake (Appetite). I: The Origins and Consequences of Obesity. Ciba Foundation Sumposium 201. Chichester: John Wiley \& Sons. 
Blundell, J. E. \& P.J. Rogers

1991 Hunger, Hedonics, and the Control of Satiation and Satiety. I: M. Friedman et al. (eds.):

Chemical Senses: Appetite and Nutrition 4:127-48.

Bordo, Susan R.

1990 The Body and the Reproduction of Feminity: A Feminist Appropriation of Foucault. I: M. A. Jagger and S. R. Bordo (eds.): Gender/Body/Knowledge: Feminist Reconstructions of Being and Knowing. New Brunswick \& London: Rutgers University Press.

Bourdieu, Pierre

1984 Distinction: A Social Critique of the Judgement of Taste. Cornwall: Routledge.

Christensen, Gudrun

1998 Diskursiv regulering af ernæringspraksis. En vidensarkæologisk og genealogisk analyse af rationaliseringstendenser i Statens Husholdningsråds pjecer om mad og ernæring 1936-1985. Ph.d.-afhandling, Forskningsinstitut for Human Ernæring, Den Kgl. Veterinær- og Landbohøjskole, København.

Dike

1997

Sundhed og sygelighed i Danmark 1994. København: Dansk Institut for Klinisk

Epidemiologi.

Douglas, Mary

1975 Deciphering a Meal. I: M. Douglas (ed.): Implicit Meanings: Essays in Anthropology.

London: Routledge \& Kegan Paul.

Fagt, Sisse \& Margit V. Groth

1992 Udviklingen i danskernes fødevareforbrug 1955-1990. København: Levnedsmiddelstyrelsen.

Fischler, Claude

1980 Food Habits, Social Change and the Nature/Culture Dilemma. Social Science Information 19(6):937-53.

1988 Cuisines and Food Selection. I: D. M. H. Thomsen (ed.): Food Acceptability.

New York \& London: Elsevier Applied Science.

1988 Food, Self and Identity. Social Science Information 27(2):275-92.

Holm, Iversen

1997 Moderne madvaner. Dansk Sociologi 4(8):37-52.

Lading, Åse

1987 Mad som øjenlyst - og ulyst. Hug 48:22-6.

Leder, Drew

1990

The Absent Body. Chicago: University of Chicago Press.

Levnedsmiddelstyrelsen

1987 Fedme - en statusrapport. København: Levnedsmiddelstyrelsen.

Lissner, Lauren

1997 Psychosocial Aspects of Obesity: Individual and Societal Perspectives.

Scandinavian Journal of Nutrition 41:75-9.

Lupton, Deporah

1996 Food, the Body and the Self. London: Sage Publications.

Scheper-Hughes, Nancy

1992 Death Without Weeping: The Violence of Everyday Life in Brazil.

Berkeley, Los Angeles, Oxford: University of Califonia Press.

Scheper-Hughes, Nancy \& Margaret Lock

1987 The Mindful Body: A Prolegomenon to Future Work in Medical Anthropology.

Medical Anthropology Quarterly 1(1):16-41. 
Simmel, Georg

1993 Måltidets Sociologi. Sociologi i dag: Måltidets Sociologi 1:3-11.

Taylor, Charles

1998

Sources of the Self: The Making of the Modern Identity.

Cambridge: Cambridge University Press.

Turner, Brian S.

1992 Kroppen i Samfundet. Teorier om krop og kultur. København: Hans Reitzels Forlag.

WHO

1997

Prevention and Management of the Global Epidemic of Obesity. Report of the WHO Consultation on Obesity, Geneva, 3-5 June, draft.

Zylan, K. D.

1996 Gender Differences in the Reasons Given for Meal Termination. Appetite 26:37-44. 